Article

\title{
The Evaluation of Single-Family Detached Housing Units in Terms of Integrated Photovoltaic Shading Devices: The Case of Northern Cyprus
}

\author{
John Emmanuel Ogbeba *(1) and Ercan Hoskara \\ Department of Architecture, Faculty of Architecture, Eastern Mediterranean University, North Cyprus, \\ 99450 Famagusta, Mersin 10, Turkey; ercan.hoskara@emu.edu.tr \\ * Correspondence: john.ogbeba@emu.edu.tr
}

Received: 6 December 2018; Accepted: 15 January 2019; Published: 23 January 2019

\begin{abstract}
In this paper, we evaluate passive and active strategies that can be used in solving the heating problems in the residential sector of Northern Cyprus. In doing so, we propose the use of photovoltaics as a shading device (PVSD). PVSD is known to produce clean energy from solar radiation and it also reduces the energy consumed for cooling. We use an empirical method to evaluate the performance of a typical family detached dwelling in Famagusta, Cyprus. The simulation result derived from the study indicates that the strategic use of PVSDs for openings oriented towards the east, west, and south can reduce its energy consumption by almost $50 \%$ in three months of the year and cut down up to $400 \mathrm{kWh}$ of energy consumption through the year, thus raising the comfort level of the building by about $20 \%$. It will also generate nearly $2800 \mathrm{~W}$ that can provide up to $50 \%$ of the electricity demand.
\end{abstract}

Keywords: renewable energy integration; shading devices; BIPV; thermal comfort; energy consumption; Northern Cyprus

\section{Introduction}

Currently, the world is using fossil fuels at an alarming rate that not only will strain the sources in the near future but will result in a great amount of pollution as well. In fact, the effect of the over dependency on the use of fossil fuel for energy generation is becoming more evident in our world today. Global warming, climate change, large carbon footprints, decreasing fossil energy sources, etc., are some of the glaring effects resulting from the over use of fossil fuels.

According to the Statistical Review of World Energy (June 2016), about 33\% of the total energy consumed globally in the year 2015 was from oil, as shown in Figure 1 [1]. Buildings have been identified as one of the largest energy consumers in the world today, accounting for approximately $40 \%$ of Europe's energy consumption. This makes buildings a major contributor to greenhouse emissions and climate change. In the case of Northern Cyprus, $70 \%$ of the energy generated is consumed by buildings (KIB-TEK) [2,3]. Northern Cyprus has no oil or gas reserves, and imports the gasoline and oil used in its entire energy generation. The state-run utility company known as the Turkish Electricity Authority (KIB-TEK) and the private sector's AKSA energy are responsible for the generation, sales, and distribution of electricity; producing a total of about 403.2 MW (KIB-TEK), as shown in Table 1 [2]. Industrial consumption of electricity is quite low in Northern Cyprus, therefore, the bulk of the electricity generated is domestically consumed; used mainly for heating and cooling buildings, or for powering electronic devices and lighting. In Cyprus, a number of residential buildings are constructed without paying attention to certain basic bio-climatic principles which eventually lead to an over-dependence on oversized active systems for cooling and heating of spaces [3]. In addition, 
the lack of insulation in most of the buildings' walls relatively increases the thermal discomfort within the interior spaces.

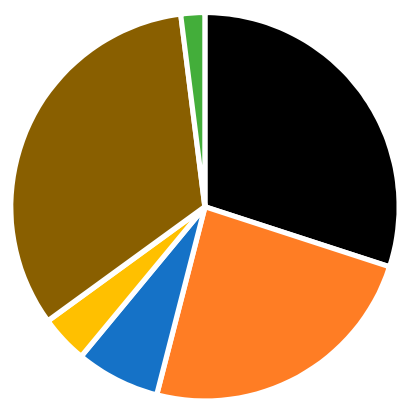

- Coal $30 \%$

- Naural Gas 24\%

- Hydro $7 \%$

- Nuclear $4 \%$

- Oil 33\%

Figure 1. World total primary energy consumption by fuel in 2015 [1].

Table 1. Total installed capacity in Northern Cyprus at the first half of 2018 [2].

\begin{tabular}{ccccc}
\hline Location & $\begin{array}{c}\text { Type of } \\
\text { Technology }\end{array}$ & $\begin{array}{c}\text { Number and } \\
\text { Sizeof Units }\end{array}$ & Fuel & $\begin{array}{c}\text { Total Installed } \\
\text { Capacity }\end{array}$ \\
\hline Teknecik & Steam Turbine & $2 \times 60 \mathrm{MW}$ & Heavy fuel oil & $120 \mathrm{MW}$ \\
Teknecik & Gas Turbine & $20 \mathrm{MW}+10 \mathrm{MW}$ & Diesel & $30 \mathrm{MW}$ \\
Teknecik & Diesel Generator & $8 \times 17.5 \mathrm{MW}$ & Diesel & $140 \mathrm{MW}$ \\
Dikmen & Gas Turbine & $20 \mathrm{MW}$ & Diesel & $20 \mathrm{MW}$ \\
Kalecik & Diesel Generator & $8 \times 17 \mathrm{MW}$ & Diesel & $136 \mathrm{MW}$ \\
Kalecik & Steam Turbine & $6 \mathrm{MW}$ & Heavy fuel oil & $6 \mathrm{MW}$ \\
Serhat & Solar & $1.2 \mathrm{MW}$ & - & $1.2 \mathrm{MW}$ \\
Total & & & $453.2 \mathrm{MW}$ \\
Total without Gas Turbines & & & $403.2 \mathrm{MW}$ \\
\hline
\end{tabular}

On the other hand, there is an increasing awareness of the environmental problems caused by the use of non-renewables [4], thus leading to a growing interest in the use of cleaner and renewable sources of energy such as wind energy, solar energy, etc. Besides, it has become obvious that the use of energy from renewable sources is the most effective way of combating climate change. Solar energy, for instance, has been identified as the most popular source of renewable energy today. The energy from solar irradiation on the earth can meet the daily energy consumption needs of mankind several thousand times over [5]. There are two basic categories of solar energy: passive and active. Passive solar energy is put into practice as a design strategy to accomplish direct or indirect space heating, daylighting, etc. [6]. Active solar energy is implemented through technical installations, such as solar collectors and photovoltaic (PV) panels.

Today, one of the most widespread technologies of renewable energy generation is the use of photovoltaic (PV) systems which convert sunlight into electrical energy. Altin opined that "solar energy is the most suitable and easiest renewable energy source that can be used in buildings" and the most popular renewable energy source $[7,8]$.

Several studies have been carried out globally that have focused on finding practical ways and methods for conserving and optimizing energy within buildings. Some of the major practical strategies used in conserving energy within building spaces include; good cross ventilation, allowing daylight into the building, and cutting down on the excessive use of electricity [9-11]. Within the Mediterranean region, several studies have also been conducted on how to use both passive and active measures to improve the indoor environment [12,13]. Moreover, lots of researchers have endeavored to emphasize the significance of housing quality and the need to establish well-designed buildings that are energy efficient [12-17]. Therefore, since no two residential buildings are exactly the same, it is quintessential to analyze the energy saving potentials of houses and their construction techniques at an individual household scale and the result can then be replicated on a wider regional scale [18].

In this paper, we evaluate passive and active strategies that can be used in solving the heating problems in the residential sector of Northern Cyprus. In doing so, the best design strategies for 
solving the overheating problem of a single-family detached house were identified and presented. The study also presented the best way to integrate PVs as shading devices. This article is divided into six sections. The first section provides a brief introduction and the aim of the study. In the second section, building-integrated photovoltaics (BIPV) and photovoltaics as a shading device (PVSD) are discussed. The third section of this study presents the context of the study location, while the methodology for the study is discussed in the fourth section. Sections 5 and 6 contain the results/findings and conclusion of the research, respectively.

\section{BIPV and PVSD}

BIPV: The term building-integrated photovoltaics (BIPVs) refers to the integration of photovoltaic panels into the building skin [19], with the dual roles of replacing building components and of simultaneously serving as electricity generators [20-22]. There have also been possibilities of BIPV products being used as façade, windows, shading elements or awnings, curtain walls, and roofs [23-27].

PVSDs: Architects always endeavor to improve the quality of interior spaces by creating openings for daylighting and views to the outside. This most often can result in excessive solar gains. Shading devices are used as a passive strategy to reduce this effect. As indicated by Schittich, shading systems help: prevent overheating in indoor spaces, adapt to different climates, reduce energy consumption for cooling and heating, provide a glare-free environment, and help to control the ventilation of indoor spaces [28]. Pester and Crick mention four different ways photovoltaic panels can be integrated on the building skin [29], as shown in Figure 2.

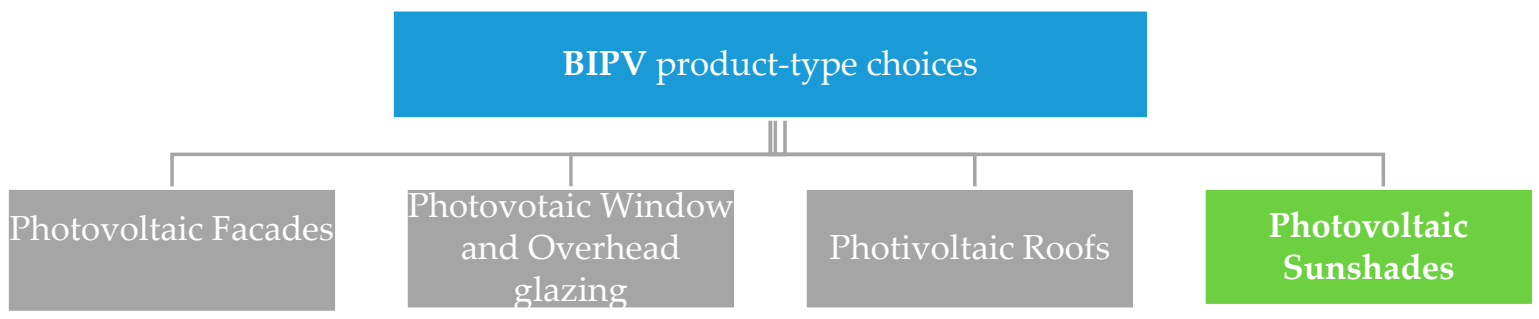

Figure 2. Four types of building-integrated photovoltaic (BIPV) product choices [29].

Although most literature focuses on the first three, the photovoltaic shading device is becoming more and more relevant for integration in buildings. The use of PVSDs is in fact more technical than the other three [30]. The use of PVSDs on buildings have economic and environmental advantages as shown in Table 2.

Table 2. Advantages of photovoltaics as shading devices (PVSDs).

\begin{tabular}{|c|c|c|}
\hline Sustainability Dimension & Benefits & References \\
\hline Environmental aspects & $\begin{array}{l}\text { Ability to produce clean energy by converting unwanted solar radiation } \\
\text { into electrical energy. There is no side effect to the ecosystem. } \\
\text { The cooling load is reduced when PVSDs are introduced. } \\
\text { When PVs are used as shading device, they generate energy and serve } \\
\text { as protection from glare, hence improving the visual comfort of the } \\
\text { users of the space, } \\
\text { enhancing specific architectural expression through the application of } \\
\text { colored and semi-transparent PV products. }\end{array}$ & [31-34]. \\
\hline Economical aspects & $\begin{array}{l}\text { The energy is generated in situ and not centrally, there are savings in } \\
\text { terms of the cost of distribution and greenfield. } \\
\text { The cost of material is saved since the PV is serving as both an energy } \\
\text { generator and as a building component. }\end{array}$ & {$[34,35]$} \\
\hline
\end{tabular}

The outcomes of the shading study of Aksugur, in his paper on the potential of passive cooling strategies in Cyprus, show that rooms with windows which are located on the south side of a building become excessively hot in summer [36]. Oktay's evaluation of vernacular housing in Northern Cyprus suggests that orienting living spaces towards the south, as well as designing a narrow building plan 
with windows on the opposite sides for cross-ventilation, are essential passive design strategies that can be used in Northern Cyprus [37]. The primary objective of using passive and active design strategies is to create a soothing micro-climate which is cool in the summers and warm in the winters [38-42].

Over the years, several strategies have been proposed that promote the use of PV systems within the residential housing stock. According to James et al., "declining module cost, growing consumer interest in solar energy and policy schemes" are some of the key factors to put into consideration [43]. Other major factors that influence the generation and consumption of energy include the location and climate data of the building, the orientation of the building, installed materials, building design, and the selection of the technical systems [44-46].

\section{The Context of the Study}

The single-family housing type case study was located in Famagusta, Cyprus, as shown in Figure 3. Cyprus is the third largest island in the Mediterranean Sea. The city of Famagusta is a coastal town and is on the east side of the island, with a seven-meter elevation above sea level [47]. The population of Famagusta is 42,526 according to the 2006 census [48].

The climate in Famagusta is a transitional one; it lies between a composite and a hot, humid climate, however, because of its close proximity to the Mediterranean Sea, it has a hot and humid climate $[49,50]$. According to the Cyprus meteorological station report about Famagusta, the temperature of Famagusta rises to more than $30{ }^{\circ} \mathrm{C}$ in the summer months and drops to a low of $3{ }^{\circ} \mathrm{C}$ in the winter months, as shown in Figure 4 . The relative humidity for the city of Famagusta is between $33 \%$ to $72 \%$ in the different months of the year. January records the highest and October the lowest humidity in the year. Famagusta has an average of $9 \mathrm{~h}$ of sunlight each day, as shown in Figure 4, and an average of $3328 \mathrm{~h}$ of sunlight in a year. The city also experiences an average of $403.5 \mathrm{~mm}$ of rainfall each year and an average of $33.6 \mathrm{~mm}$ each month [49].

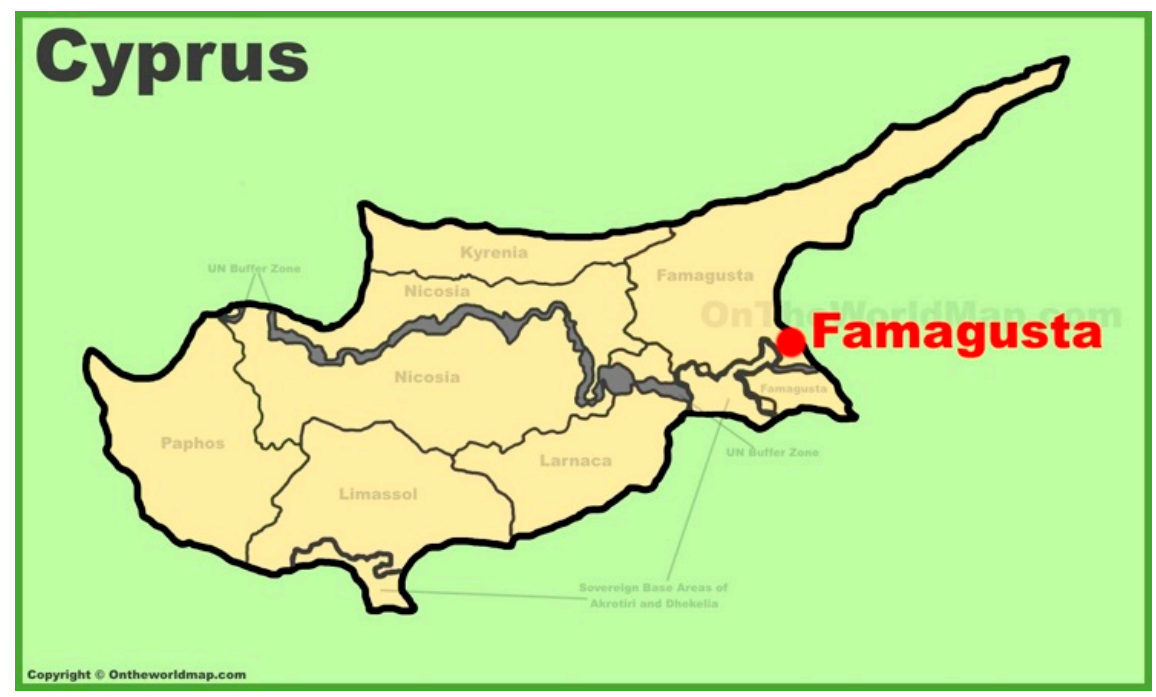

Figure 3. Location of Famagusta city in Cyprus [51].

The most comfortable months of the year are the months of April, May, October, and November, while the months of December, January, February, and March require heating. The summer months of June, July, August, and September require cooling and ventilation [52]. According to [53], Famagusta has high solar energy during the winter $\left(5.26 \mathrm{kWh} / \mathrm{m}^{2} /\right.$ day), which rises to $7.12 \mathrm{kWh} / \mathrm{m}^{2} /$ day during the summer season, as shown in Figure 6. In addition, the total solar radiation in Famagusta usually rises from $6 \mathrm{MJ} / \mathrm{m}^{2}$ in December to a high of about $24 \mathrm{MJ} / \mathrm{m}^{2}$ in June and July. Besides, the energy generation rises from $70 \mathrm{~W} / \mathrm{m}^{2}$ in December to $280 \mathrm{~W} / \mathrm{m}^{2}$ in June and July [54,55]. 


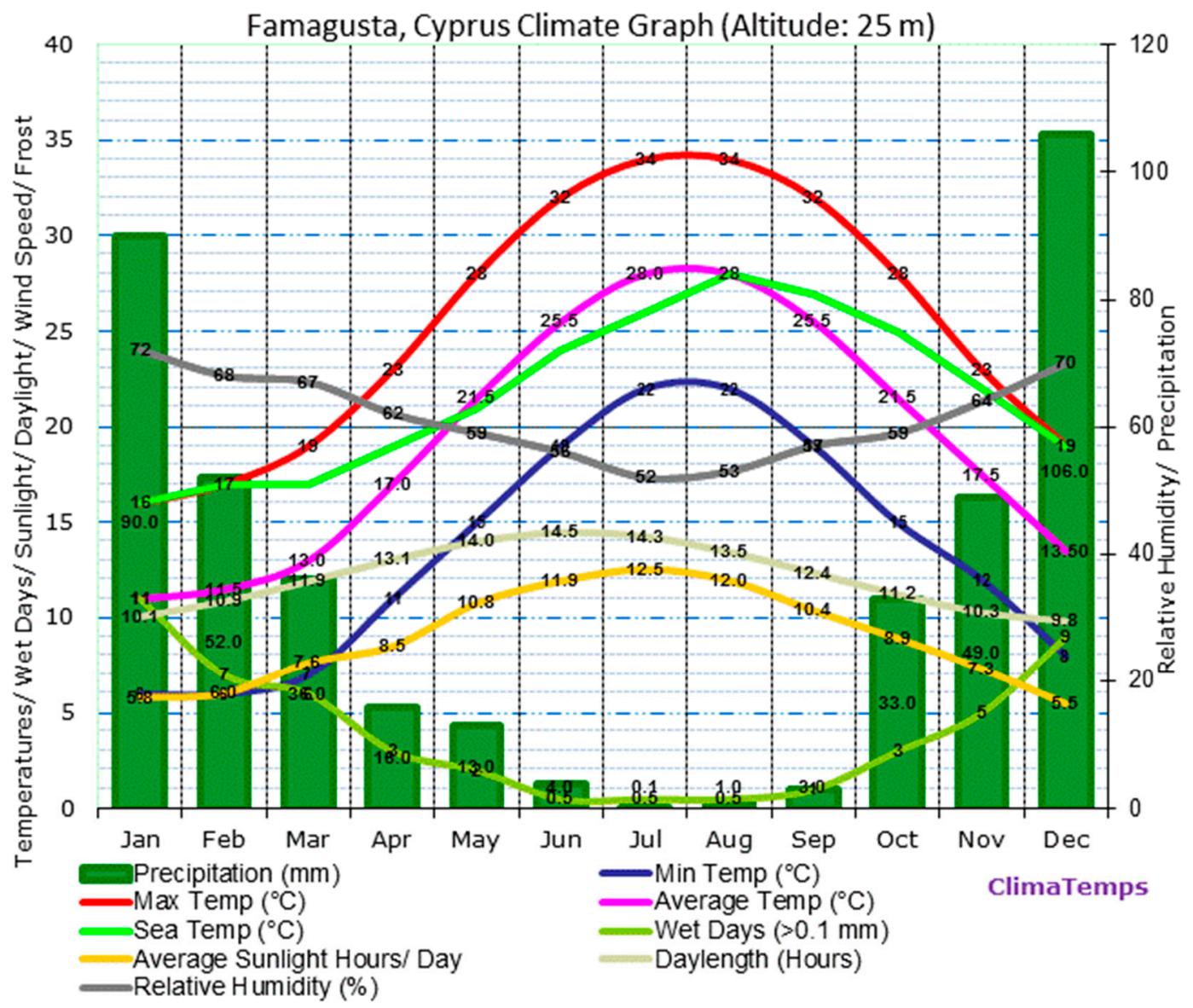

Figure 4. Annual climate graph of Famagusta [53].

Figures 5 and 6 illustrate that the countrywide solar potential of Cyprus is the highest in Europe. Moreover, studies have shown that a polycrystalline or monocrystalline solar PV system with nominal power of $1 \mathrm{~kW}$ installed in the coastal region of Cyprus, with a $27^{\circ}$ still angle of the panels and south direction, produces on average more than $1500 \mathrm{kWh}$ per year throughout the first 20 years of its operation [56]. This is a clear indication of why the government should invest in solar energy as an alternative source of energy.

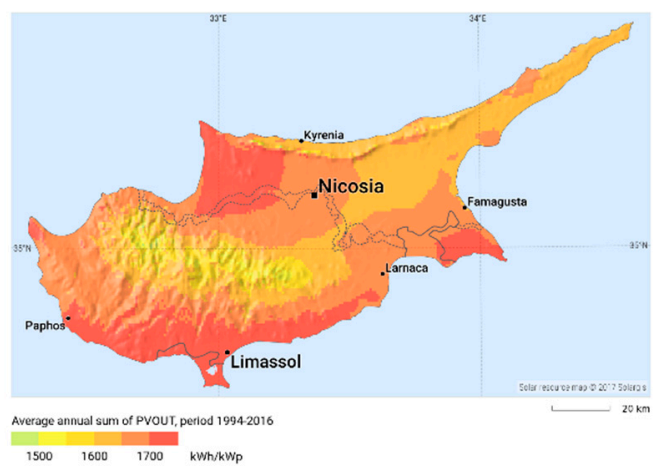

Figure 5. Photovoltaic power potential in Northern Cyprus [57]. 


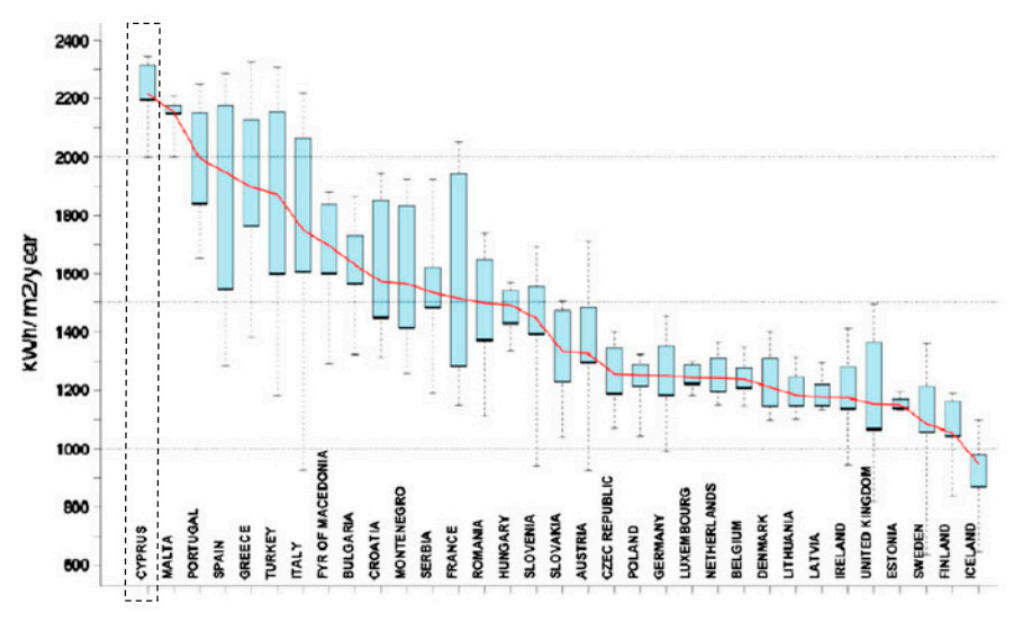

Figure 6. Photovoltaic power potential in Northern Cyprus [56].

\section{Materials and Methodology}

To achieve the objectives of this research, both qualitative and quantitative methodology were employed, as shown in Figure 7. The qualitative method included a wide-ranging survey of relevant literature, while the quantitative method involved a model set up. Firstly, a typical single-family house was chosen for the simulation. A building simulation model was generated to reproduce the interior and outside of the house, as well as the materials used for the construction of the building. The computer program DesignBuilder was used. This software uses EnergyPlus ${ }^{\mathrm{TM}}$, a simulation software developed by the US Department of Energy (DOE) to simulate heat transfer processes, climate conditions, and other factors relating to energy consumption in buildings. EnergyPlus ${ }^{\mathrm{TM}}$ is a whole building energy simulation program that researchers and professionals in the building industry use to model both energy consumption for heating, cooling, ventilation, lighting, and plug and process loads-and water use in buildings [58,59].

Furthermore, the Climate Consultant program and the weather file of Famagusta (epw) was used to develop the best strategies for both passive and active design that would create a unique list of design guidelines for the building. The building was simulated with and without shading devices, and finally with the shading devices replaced with PVs. The ASHRAE Standard 55 was also used as the comfort model in the Climate Consultant simulation. Milne describes Climate Consultant as a graphic-based computer program that helps users create more energy efficient buildings, each of which is uniquely suited to its particular location in the world [60]. 


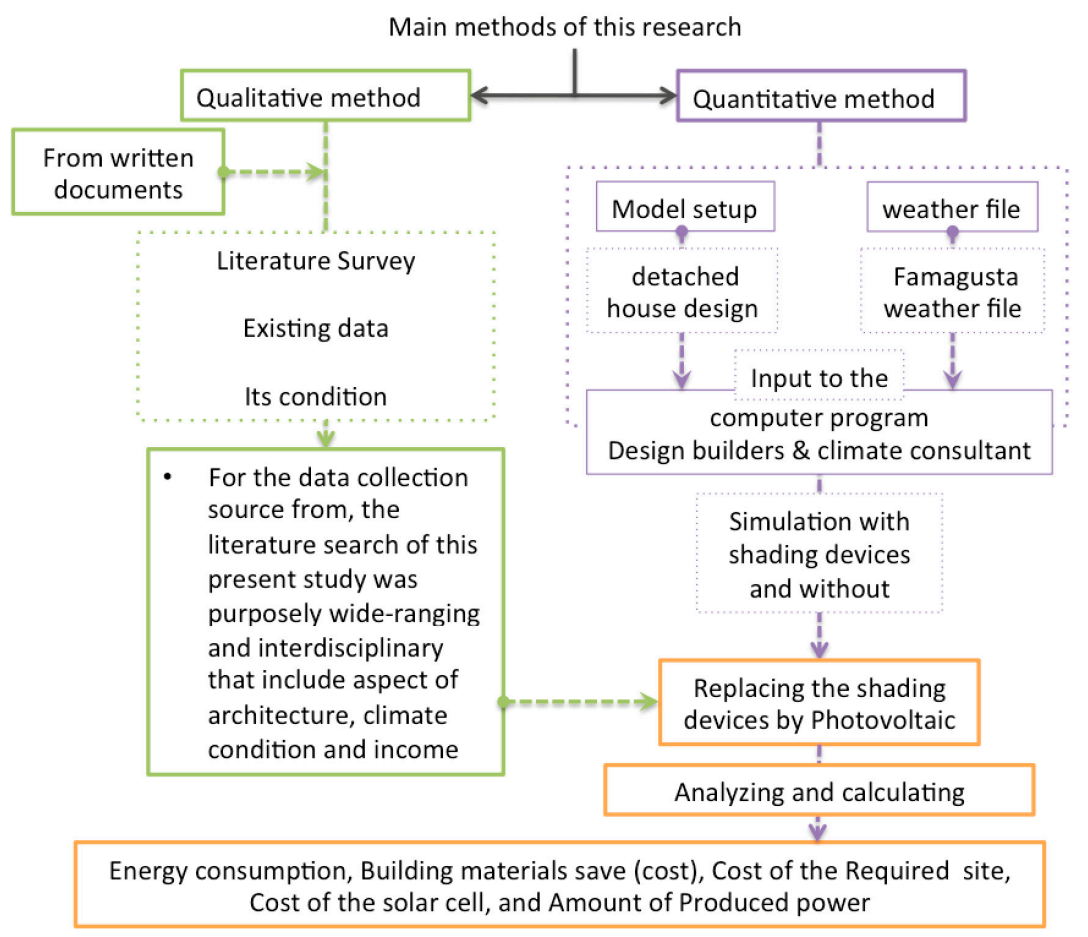

Figure 7. Illustration diagram of process and methodology of the research (drawn by authors).

\section{Building and PVSD Case Study}

For the model setup, a common single-family detached dwelling with a living room, a garage, a kitchen, two bathrooms, and five bedrooms was evaluated using DesignBuilder software. The house has a south orientation, a flat roof, and a total floor area of $149 \mathrm{~m}^{2}$. The details about the building model are shown in Figure 8 and Table 3.
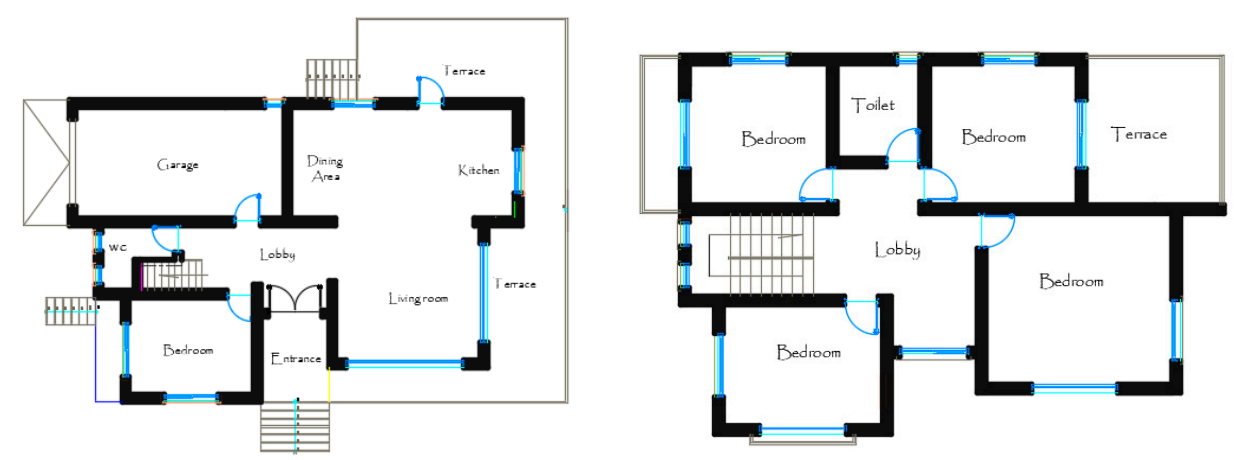

(a)

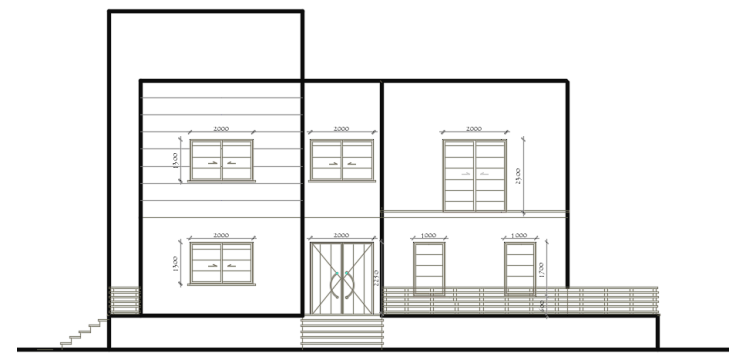

(b)

Figure 8. (a) Ground first floor of the building model; (b) elevation of the building. 
Table 3. Information about the single-family building model.

\begin{tabular}{ccc}
\hline $\mathbf{s} / \mathbf{n}$ & Building Information & Description \\
\hline 1 & Project & Residential building \\
2 & Type & Single family detached house \\
3 & Area of building & $149 \mathrm{~m}^{2}$ \\
4 & Climatic region & Mediterranean climate \\
5 & Orientation: & South \\
6 & Number of floors & Two floors \\
7 & Window material & PVC \\
8 & Window configuration & Double glazing \\
9 & Windows type & 3 mm clear glass + 6 mm air gap + \\
10 & Level above ground & 3 mm clear glass \\
11 & Orientation of the openings & $1 \mathrm{~m}$ \\
12 & Outside shading device & South, east, west, and north \\
13 & Door material & Louver and cantilever \\
14 & Wall type & Wood \\
15 & HVAC system & Bearing and partition \\
& & Slit unit \\
\hline
\end{tabular}

EnergyPlus operational and occupancy schedules default values for residential buildings were used for the simulation. The building's energy demand includes; lighting, domestic hot water (DHW), air-conditioning system, and other household appliances. The DesignBuilder software's default residential operational schedule was used to determine the building's electricity requirements. The input parameters and boundary conditions for the EnergyPlus simulation used to determine the light, DHW, and other appliances are given in Table 4. The heat transfer coefficients of the construction elements of the building were obtained from [61] for the heating and cooling load calculations and are tabulated in Table 5 .

Table 4. Parameters for residential electricity demand. DHW: domestic hot water.

\begin{tabular}{ccc}
\hline Lighting & Illuminance (lux) & $\mathbf{1 5 0}$ \\
\hline \multirow{2}{*}{ DHW } & Consumption rate $(\mathrm{l} / \mathrm{m} 2$-day) & 0.72 \\
Equipment & Delivery temperature $(\mathrm{C})$ & 65 \\
\hline
\end{tabular}

Table 5. Heat transfer coefficient (U) for construction components [61].

\begin{tabular}{ccccc}
\hline \multirow{2}{*}{ City } & \multicolumn{4}{c}{ U-Value $\left(\mathbf{W} / \mathbf{m}^{2} \mathbf{k}\right)$} \\
\cline { 2 - 5 } & Wall & Roof Ceiling & Floor & Windows \\
\hline $\begin{array}{c}\text { Famagusta } \\
\text { Northern Cyprus }\end{array}$ & 0.56 & 0.67 & 0.44 & 0.8 \\
\hline
\end{tabular}

\section{Result and Findings}

This section of the paper presents the results from the simulation of the case study.

\subsection{Sun Shading Chart}

From the Climate Consultant program, the number of hours that shading is required for the simulated building was derived. The result of the simulation presented in Figures 9 and 10 show the annual number of hot, cold, and comfortable hours in the simulated building. Between the winter and spring months (21 December to 21 June), shade would be needed for $174 \mathrm{~h}$, the sun will be needed for $1590 \mathrm{~h}$, and $748 \mathrm{~h}$ are the comfortable hours within this period of the year. While for the summer months as shown in Figure 10 (21 June to 21 December), shading will be required for $1203 \mathrm{~h}$, direct solar 
radiation for heating is required in the building for $499 \mathrm{~h}$, and the remaining $896 \mathrm{~h}$ are the comfortable hours of the year.
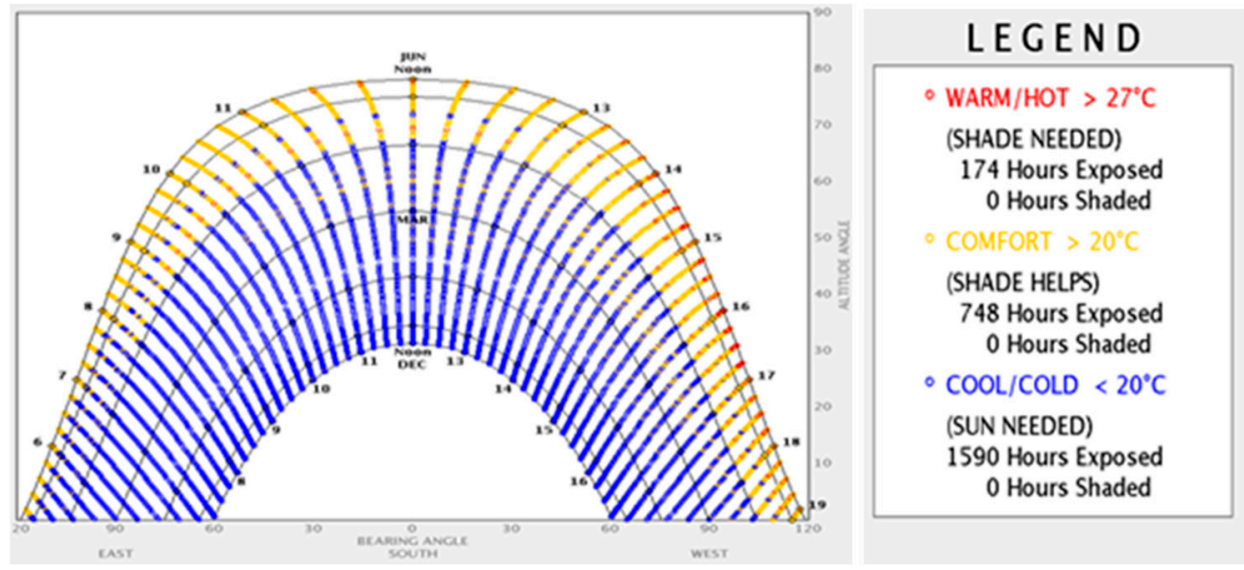

Figure 9. Sun shading chart in winter and spring (21 December to 21 June).

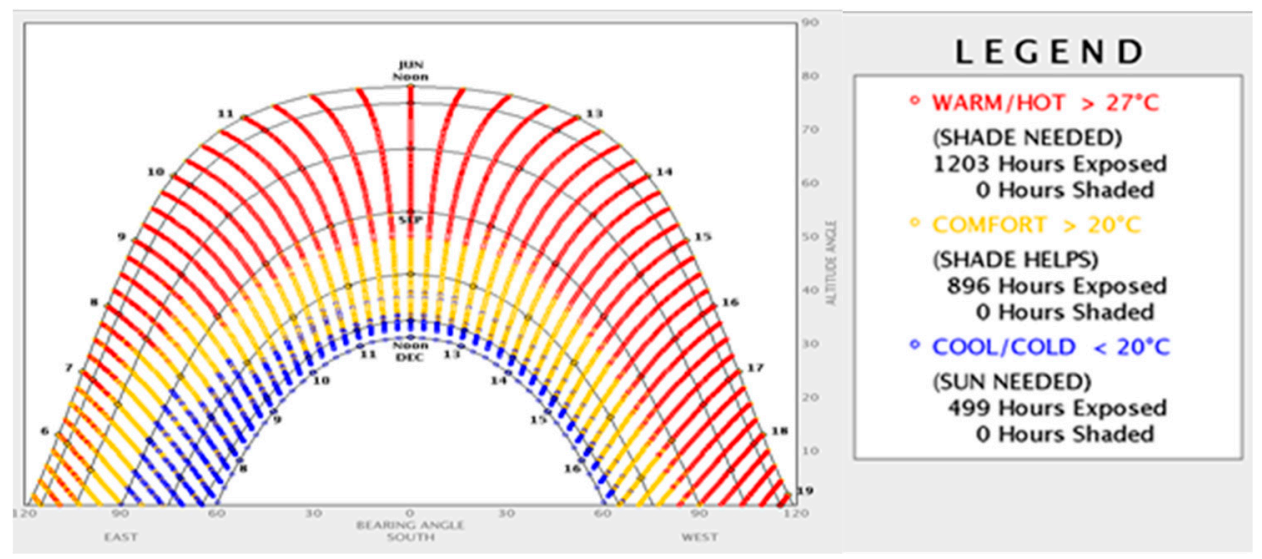

Figure 10. Sun shading chart in summer and fall (21 June to 21 December).

Furthermore, from Figures 9 and 10, we can deduce that the two-floor single-family house, which is classified as a low-rise residential building, needs shading devices for a total of $1218 \mathrm{~h}$ in a year.

\subsection{Psychrometric Chart Results}

One very important output of the Climate Consultant software is the psychrometric chart. Beyond just representing the climatic data, the psychometric chart helps to organize the information in a way that is plain and easy for people to understand the influence of climate on the immediate environment. The Comfort Zone, as shown in Figure 11, is the psychrometric chart for the simulated house. It can be clearly seen that the area of the comfort zone for the building is quite small $(16.8 \%)$, implying that a large amount of energy would be needed for heating and cooling. Therefore, very good passive and active design strategies need to be developed to solve the heating problem. 


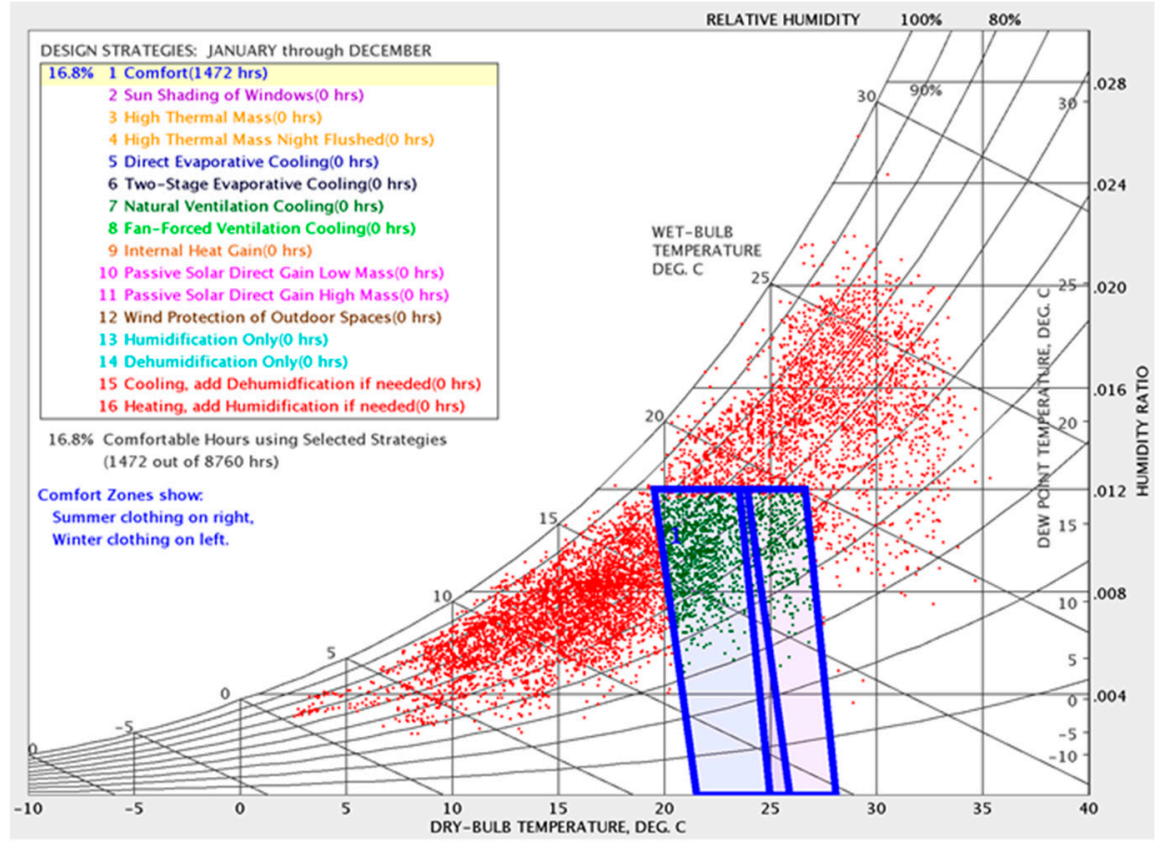

Figure 11. Psychrometric chart for Famagusta: Comfort Zone.

Figure 12 presents the best design strategies for building envelopes in Famagusta. The strategies are able to modify or filter extreme external climate conditions to create comfortable indoor environments in Famagusta.

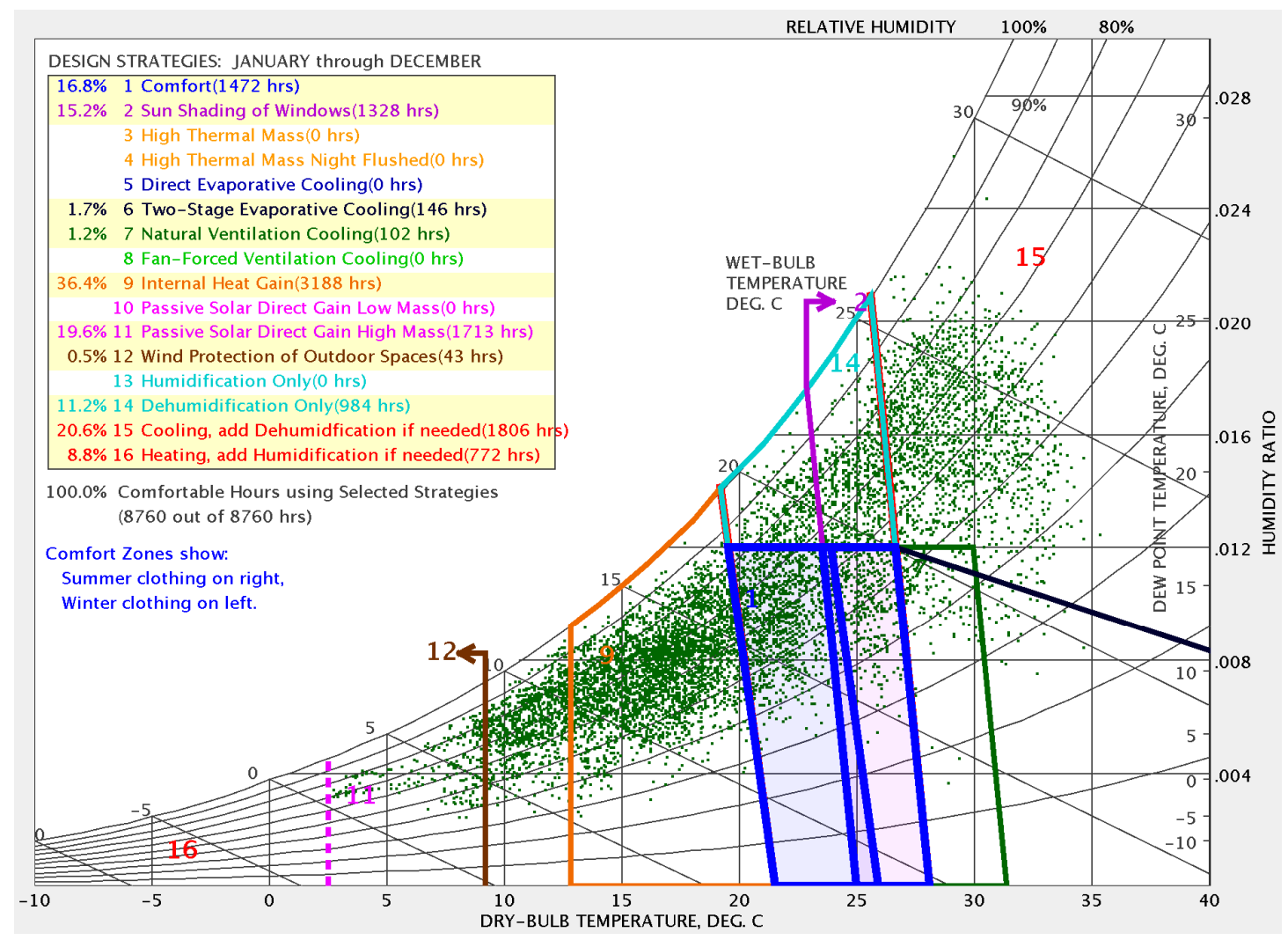

Figure 12. Psychrometric chart for Famagusta.

The design strategies for the simulated building are explained as follows: 
- Sun shading of windows: as presented in Figure 15, shading on the chart takes up to $15.2 \%$ that is about $1328 \mathrm{~h}$ of the year. Through the use of shading devices, 1328 uncomfortable hours are converted to comfortable hours.

- Two stage evaporative cooling: in the two-stage evaporative cooling strategy, first a thermal converter is used to reduce the temperature, then the comfort condition is applied by direct evaporative cooling. This process makes up $1.7 \%$ (146 $\mathrm{h}$ annually).

- Natural ventilation cooling: natural ventilation is required for cooling for about $102 \mathrm{~h}$ of the year $(1.2 \%)$.

- Internal heat gain: $36.4 \%$ of thermal comfort can be achieved by internal heat gained from within the building from artificial lighting, electrical equipment, and indoor activities by occupants. This is about $3188 \mathrm{~h}$ of the year.

- Passive solar direct gain high mass: the is the number of hours in the year where thermal comfort is achieved through passive solar gain. This includes a total of about $1713 \mathrm{~h}(19.6 \%)$.

- Wind protection of outdoor spaces: in this segment of the chart, building wind protection by outdoor elements such as plants is required to achieve the comfort conditions. This includes $0.5 \%$ making up a total of $43 \mathrm{~h}$ of the year.

- Dehumidification only: dehumidification is required to achieve thermal comfort in the building for a total of about $984 \mathrm{~h}$ of the year, making up $11.2 \%$.

- Cooling, add humidification if needed: to achieve comfort, this strategy requires both cooling and humidification at the same time. This includes a total of $1806 \mathrm{~h}$ of the year (20.6\%).

- Heating, add humidification if needed: to achieve comfort, this strategy requires both humidification and increasing air temperature by mechanical heating. This includes a total of $772 \mathrm{~h}$ of the year $(8.8 \%)$.

\subsection{Solar Shading Performance Result}

Solar shading performance was also assessed using Climate Consultant. Shading elements work differently based on their orientation. Shading device strategies are usually tailored towards the orientation of each window. Whilst some orientations are easy to shade, others are much more difficult as the sun can be almost direct-on at certain times of the day. The number of hours exposed to the sun that need to be shielded is also different based on the direction the façade is facing (north, south, east, and west). From the simulation, the types of shading elements that should be used are also different, as illustrated in Figures 13 and 14. The results from the simulation are that:

- Windows directly facing the south would need more shading from the sun, and the horizontal overhangs work better for southern façades. The east and west would require both vertical fins and horizontal overhanging used in the passive design strategies, while on the northern façade, shading is completely avoided as exposure to the sun is needed for the interior space of the building.

By having shading devices with PV integrated retrofits, shading can be provided, and electricity generated simultaneously, which is what this research seeks to achieve.

Having identified shading as one of the best strategies, the next step would be to identify what shading system best fits the orientation of the building. Through the use of Climate Consultant, this study has been able to identify the best shading strategy that best fits the single-family building location, as shown in Figure 13. 


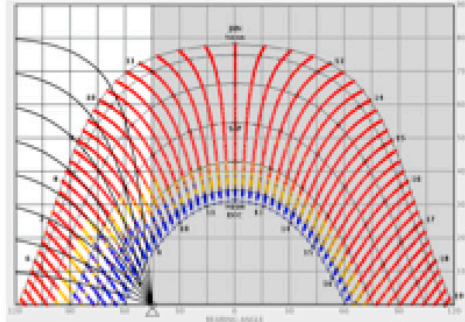

Northem east

346 Hours Exposed

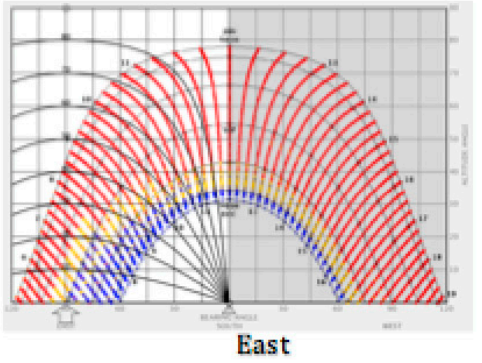

434 Hours Exposed

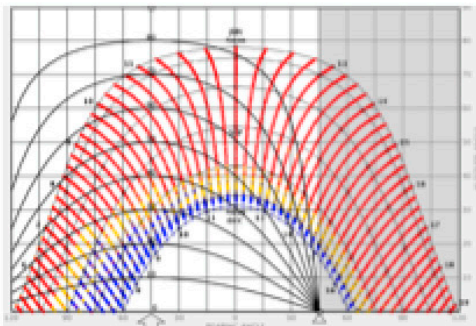

Southern east 620 Hours Exposed

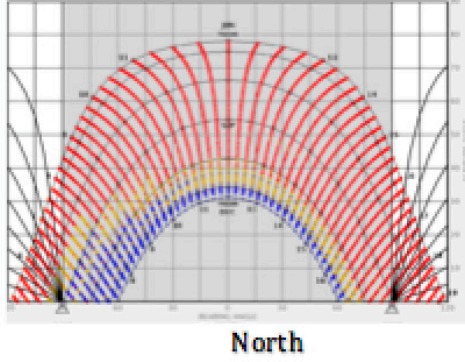

88 Hours Exposed
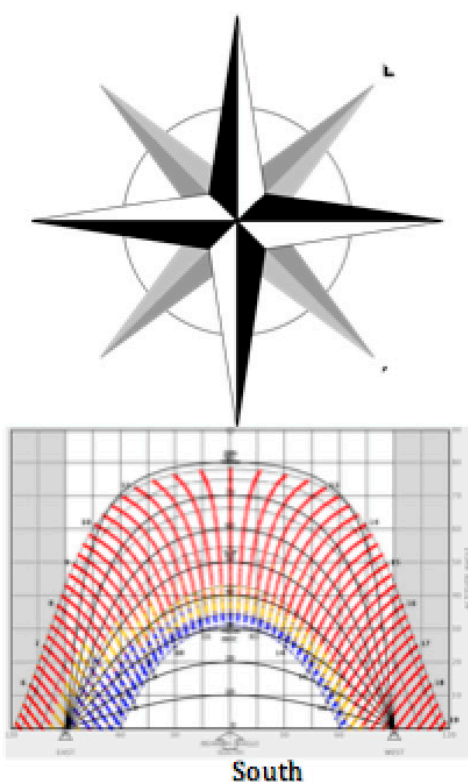

957 Hours Exposed

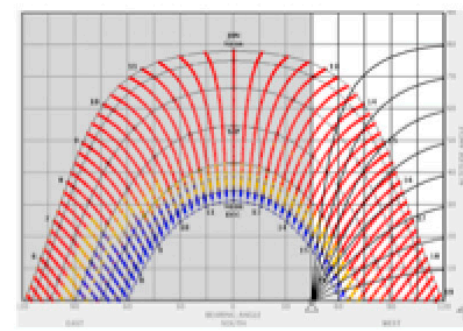

Northern west

741 Hours Exposed

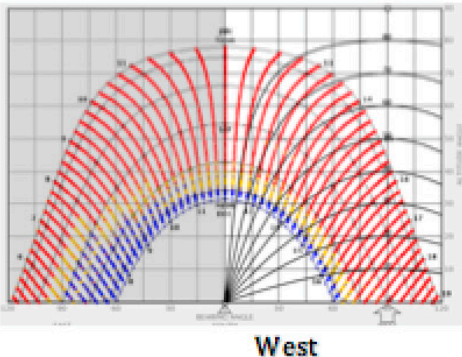

830 Hours Exposed

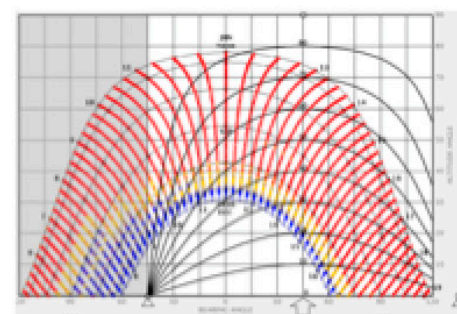

Southern west

1016 Hours Exposed

Figure 13. The Shading Calculator Overlay in eight different orientation cases by focusing on sun exposure during June 21 to December 21.

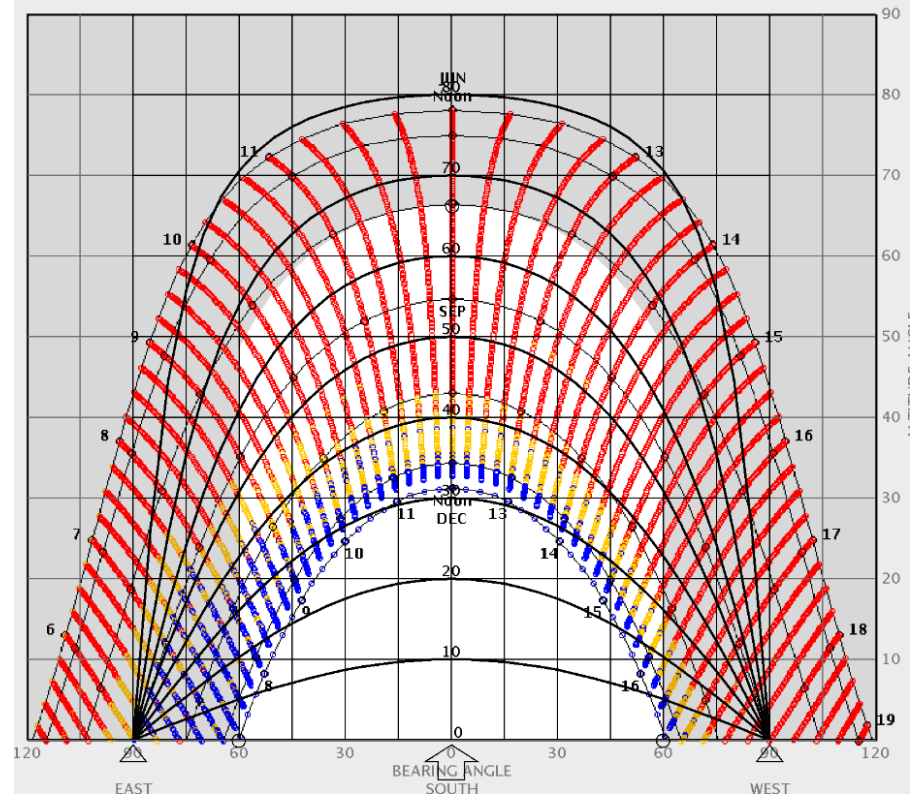

Figure 14. Overhang angle and vertical fin angle. 


\subsection{Cooling Design Strategy}

The cooling design is aimed at solving the overheating problem of the building, especially in the summer months. Figures 15 and 16 show the cooling design calculation, the size of the cooling plan required in design during the summer condition, and the impact of the changing aspects of shading to help find a design solution.

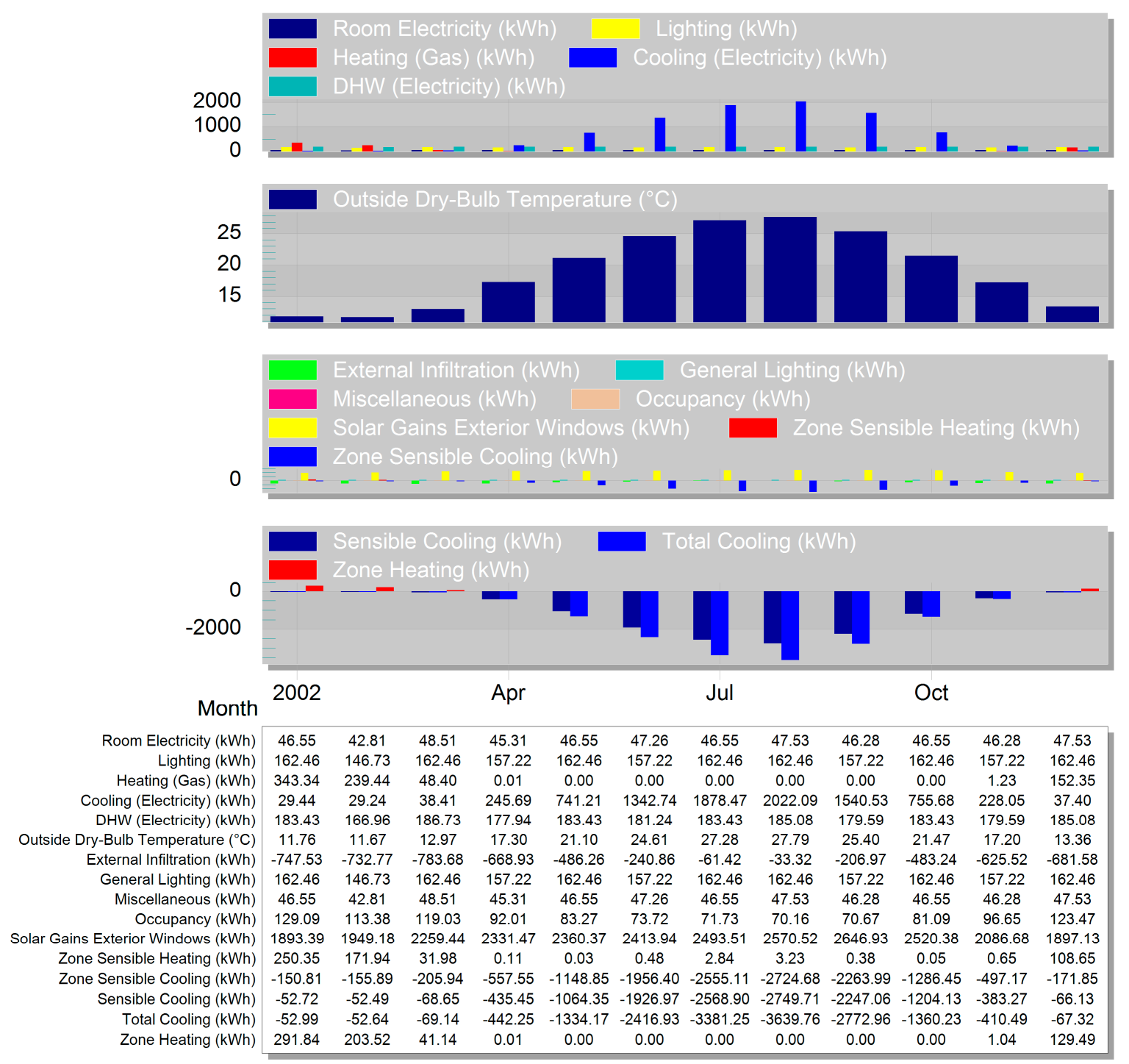

Figure 15. Simulation results without shading on a monthly basis: Temperature, Heat Gains, and Energy Consumption-1, Building 1. EnergyPlus 1 Output 31 December (zone conditions reported for occupied periods, defined by schedule) Monthly Evaluation. 


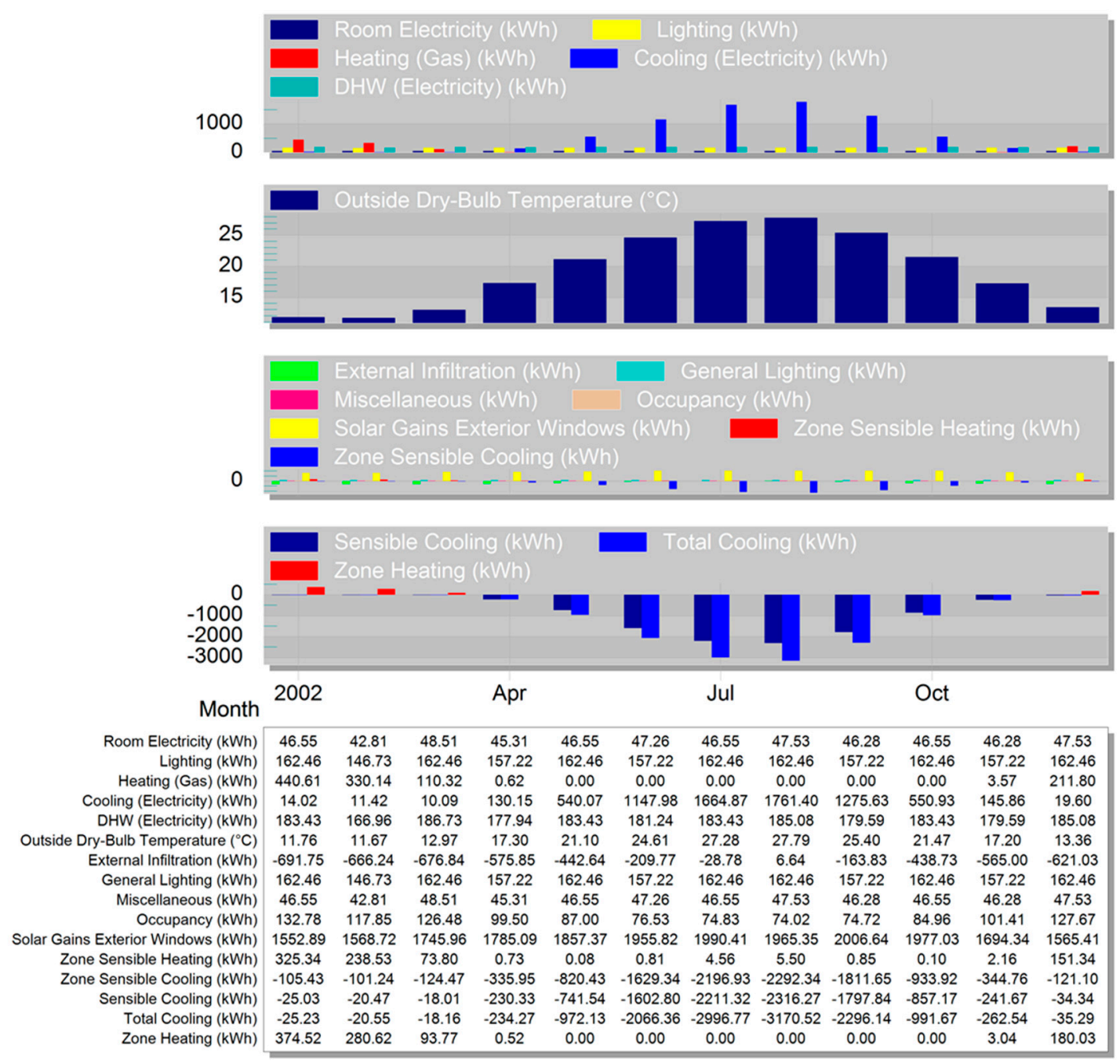

Figure 16. Simulation results with shading devices on a monthly basis: Temperature, Heat Gains, and Energy Consumption-1, Building 1. EnergyPlus 1 Output 31 December (zone conditions reported for occupied periods, defined by schedule) Monthly Evaluation.

Figure 18 shows that the amount of energy needed for cooling the sample building is very high, especially in the summer months of June, July, August, and September. Implementing the shading device strategies derived from the solar shading performance result of this research would lead to a more than $400 \mathrm{kWh}$ reduction, especially in some of the summer months, and the entire annual cooling load reduced by almost half (total cooling load-Figure 16). From the simulation, the total energy consumption that will be reduced in the summer months of June, July, August, and September is $716.02 \mathrm{kWh}$. On the other hand, the heating load increases in winter but not in a significant measure. The increase in the heating load for winter months of December, January, February, and March amounts to $115.70 \mathrm{kWh}$. In this tradeoff, the reduction in energy consumption in the summer months still outweighs the increase in the winter months.

\subsection{Total Energy Generated by the PVSDs and Cell Type}

The type of solar cell used for the simulation is the monocrystalline cell. One meter squared of monocrystalline cell produces 160 watts as earlier mentioned. Since there is $20.4 \mathrm{~m}^{2}$ available surface for integration, the PV shading device will generate a total of about 3264 watts of electricity and from due south with every $5^{\circ}$, the average deficiency drop is about $1.1 \%$ with the number of windows oriented to both east and west. 
Total of surface area of shading devices on the ground floor that are exposed to the sun:

$$
(1.8+1.4) \times 0.4+(2.3+1.4) \times 0.4+3.2 \times 0.4+4.9 \times 0.4+(4.4+2.0) \times 0.4+(2.3+1.4) \times 0.4=10.08 \mathrm{~m}^{2}
$$

Surface area of shading devices on the first floor that are exposed to the sun:

$$
\begin{gathered}
(2.6+1.9) \times 0.4+(1.8+1.4) \times 0.4+(2.3+1.4) \times 3.0 \times 0.4+2.0 \times 0.4+2.4 \times 0.4+ \\
(2.9+1.2) \times 0.4+(2.8) \times 0.4=10.28 \mathrm{~m}^{2}
\end{gathered}
$$

Total surface area $=10.08+10.28=20.36 \approx 20.4 \mathrm{~m}^{2}$

Figures 17 and 18 show the layout and the perspective view of the simulated building. Figure 17a shows the building without the PVSD, while 17b shows the building with the PVSD. Figure 19 shows the PVSD system integrated into the simulated building.

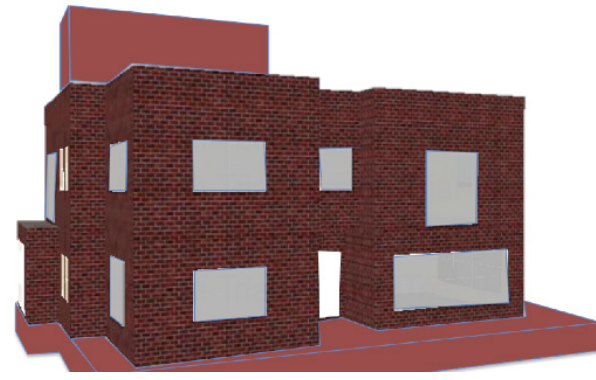

(a)

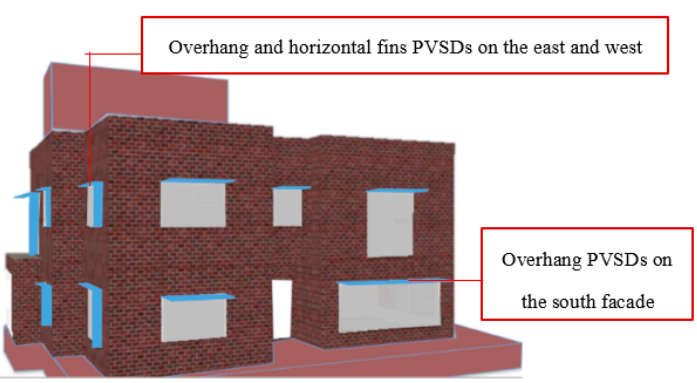

(b)

Figure 17. (a) Without shading devices; (b) with shading

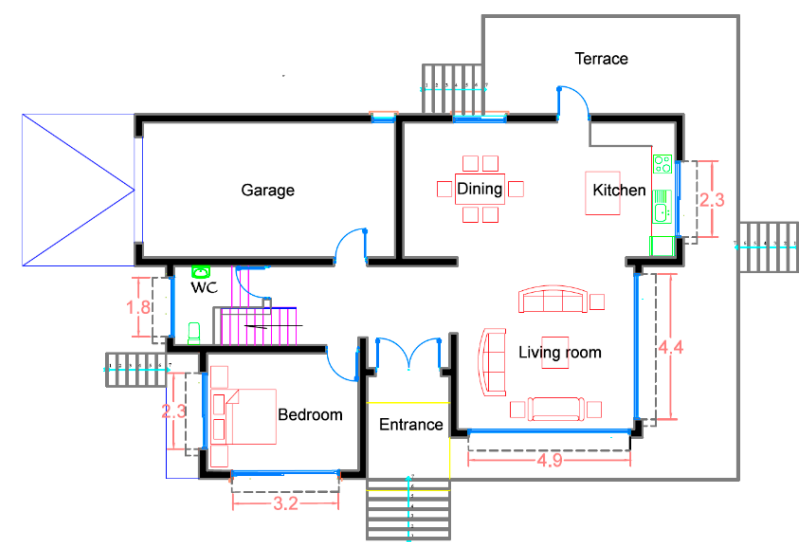

(a) Ground floor plan

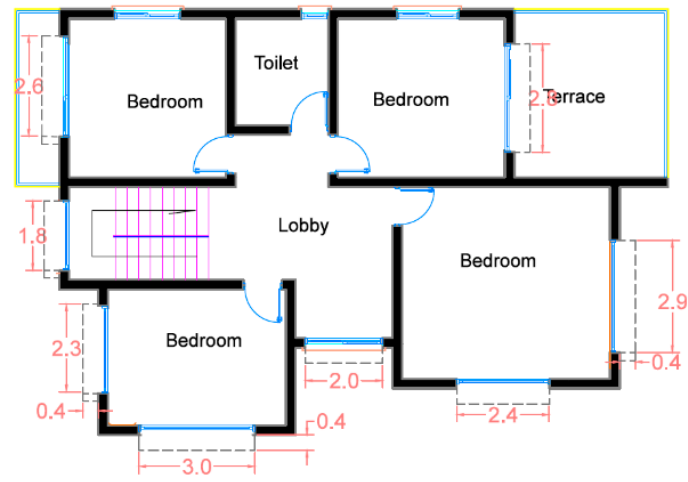

(b) First floor plan

Figure 18. Building layout with the shading device. (a) Ground floor plan, (b) First floor plan. 


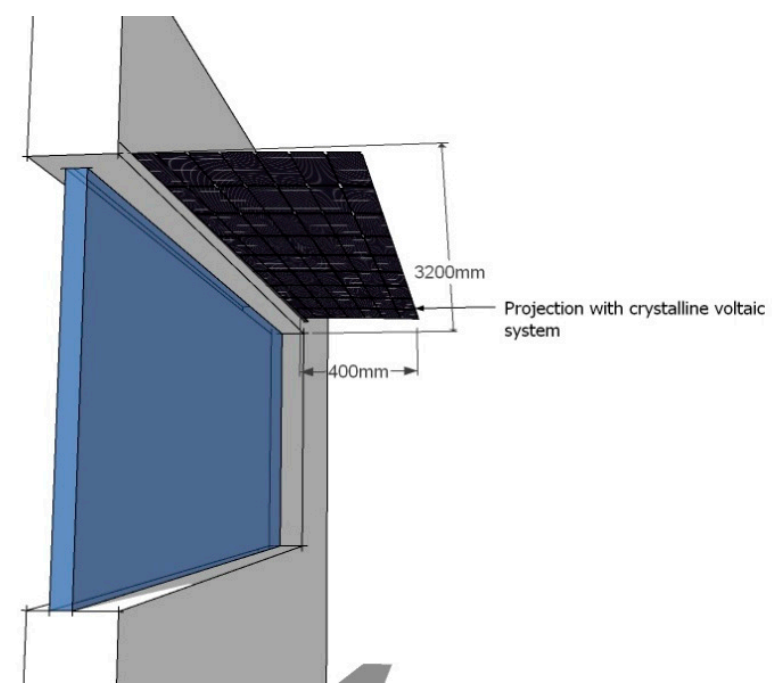

Figure 19. PVSD system used on south façade with mono crystalline photovoltaic system (authors).

Thus, the number of watts decreases. Also, according to the global formula calculation of the solar PV energy output of a photovoltaic system [62]:

$$
\mathrm{E}=\mathrm{A} \times \mathrm{r} \times \mathrm{H} \times \mathrm{PR}
$$

where

$\mathrm{E}=\operatorname{energy}(\mathrm{kWh})$,

A = total solar panel area $\left(20.4 \mathrm{~m}^{2}\right)$,

$\mathrm{r}=$ solar panel yield (estimated to be $12 \%$ ),

$\mathrm{H}=$ annual average irradiation on tilted panels (1800), and $\mathrm{PR}=$ performance ratio, coefficient for losses (0.75). The energy becomes more than $3300 \mathrm{kWh} /$ annum.

\section{Conclusions}

Openings and proper orientation for buildings within the Mediterranean region have always played a critical role in enhancing the comfort level of users. Nevertheless, it comes with a price; it often leads to overheating of the interior space in summer or inadequate penetration of sunlight in winter, especially when the building lacks proper orientation. The result is high energy consumption for heating and cooling. Therefore, developing good strategies that will conserve energy as well as generate clean energy for buildings in Cyprus and other countries facing the Mediterranean Sea is critical. Today, there are several strategies as well as new technology/products that have been designed to enhance the architectural integration of PVs in buildings. Openings on the south façade are often considered most appropriate for integration. This research provides strategies for increasing the comfort level in buildings through the integration of PVs into shading elements in the residential building. Having conducted an empirical study on the use of PVs as a shading device through a simulation on a typical single-family house, this study proposes the use of photovoltaic integrated shading instead of reinforced concrete, which is the commonly used building material for shading devices.

Based on the aim and objectives of this research work, parameters analyzed, and the building simulation, the following conclusions have been obtained:

The simulation result derived from the single-family detached house in Famagusta indicates that the strategic use of PVSDs for openings oriented towards the east, west, and south can reduce its energy consumption by almost $50 \%$ in three peak months of the year.

The integration of PVSDs cut down up to $400 \mathrm{kWh}$ of energy consumption through the year and raises the comfort level of the building by about $20 \%$. 
PVSDs used as a shading device inclined at $0^{\circ}$ will provide nearly 2800 watts that can provide up to $50 \%$ of the electricity demand of the single-family building.

The cost of the substituted materials and greenfield that would otherwise have been used to mount the panels will be saved.

The authors recommend the use of horizontal overhang on the south façade, while on the east and west façade, overhanded and fins are most appropriate.

Author Contributions: Conceptualization, J.E.O. and E.H.; Methodology, J.E.O. and E.H.; Software, J.E.O.; Validation, E.H., J.E.O.; Formal analysis, J.E.O.; Investigation, E.H.; Resources, J.O., E.H.; Data curation, J.E.O.; Writing —original draft preparation, J.E.O. and E.H.; Writing—review and editing, J.E.O. and E.H.; Visualization, J.E.O.; Supervision, E.H.; Project administration, E.H. and J.E.O.

Funding: This research received no external funding.

Acknowledgments: The authors gratefully acknowledge Wezha Hawez Baiz for her invaluable contributions to the success of this paper.

Conflicts of Interest: The authors declare no conflict of interest.

\section{References}

1. Statistical Review of World Energy (June 2016). Available online: https://www.bp.com/en/global/ corporate/energy-economics/statistical-review-of-world-energy.html (accessed on 10 November 2018).

2. KIB-TEK (2018). Available online: https://www.kibtek.com/ (accessed on 5 December 2018).

3. Elinwa, U.K.; Radmehr, M.; Ogbeba, J.E. Alternative energy solutions using BIPV in apartment buildings of developing countries: A case study of North Cyprus. Sustainability 2017, 9, 1414. [CrossRef]

4. Ozbalta, T.G. Fotovoltaik teknolojisi ile bina kabuğunun degisen işlevleri ve yüzeyleri; Dizayn Konstrüksiyon Issue 281; Anadolu Üniversitesi Mimarlık Fakultesi: Eskişehir, Turkey, 2009; pp. 75-81.

5. Jelle, B.P.; Breivik, C.; Røkenes, H.D. Building integrated photovoltaic products: A state-of-the-art review and future research opportunities. Sol. Energy Mater. Sol. Cells 2012, 100, 69-96. [CrossRef]

6. Ali, M.M.; Armstrong, P.J. Overview of sustainable design factors in high-rise buildings. In Proc. of the CTBUH 8th World Congress; CTBUH: Chicago, IL, USA, 2008; pp. 3-5.

7. Altin, M. Binaların Enerji Ihtiyacinin PV Bilesenli Cepheler ile Azaltilmasi 3. Ulusal Cati ve Cephe Kaplamalarinda Cagdas Malzeme ve Teknolojileri Sempozyumu. 17-18 Ekim 2006, ITU Mimarlık Fakultesi, Taskisla. Retrieved from World Wide Web on 1 June 2011. Available online: http:/ / www.catider.org.tr/pdf/ sempozyum/Bil7.pdf (accessed on 10 October 2018).

8. Das, S.K.; Verma, D.; Nema, S.; Nema, R.K. Shading mitigation techniques: State-of-the-art in photovoltaic applications. Renew. Sustain. Energy Rev. 2017, 78, 369-390. [CrossRef]

9. Garde, F.; Bastide, A.; Wurtz, E.; Achard, G.; Dobre, O.; Thellier, F.; Ottenwelter, E.; Ferjani, N.; Bornarel, A. ENERPOS: A National French Research Program for Developing New Methods for the Design of Zero Energy Buildings, CESB 07; Central Europe towards Sustainable Buildings: Prague, Czech Republic, 2007.

10. Li, X.; Strezov, V. Energy and Greenhouse Gas Emission Assessment of Conventional and Solar Assisted Air Conditioning Systems. Sustainability 2015, 7, 14710-14728. [CrossRef]

11. Zhai, X.Q.; Wang, R.Z.; Dai, Y.J.; Wu, J.Y.; Xu, Y.X.; Ma, Q. Solar integrated energy system for a green building. Energy Build. 2007, 39, 985-993. [CrossRef]

12. Imal, M.; Yılmaz, K.; Pınarbaşı, A. Energy Efficiency Evaluation and Economic Feasibility Analysis of a Geothermal Heating and Cooling System with a Vapor-Compression Chiller System. Sustainability 2015, 7, 12926-12946. [CrossRef]

13. Nocera, F.; Faro, A.L.; Costanzo, V.; Raciti, C. Daylight Performance of Classrooms in a Mediterranean School Heritage Building. Sustainability 2018, 10, 3705. [CrossRef]

14. Costanzo, V.; Evola, G.; Marletta, L.; Nascone, F.P. Application of Climate Based Daylight Modelling to the Refurbishment of a School Building in Sicily. Sustainability 2018, 10, 2653. [CrossRef]

15. Dunn, J.R.; Hayes, M.V. Social inequality, population health, and housing: A study of two Vancouver neighborhoods. Soc. Sci. Med. 2000, 51, 563-587. [CrossRef]

16. Sadalla, E.K.; Sheets, V.L. Symbolism in building materials: Self-presentational and cognitive components. Environ. Behav. 1993, 25, 155-180. [CrossRef] 
17. Halpern, D. Mental Health and the Built Environment: More Than Bricks and Mortar? Routledge: Abingdon, UK, 2014.

18. Liu, Z.; Osmani, M.; Demian, P.; Baldwin, A.N. The Potential Use of BIM to Aid Construction Waste Minimalization; Centre Scientifique et Technique du Bâtiment: Marne-la-Vallée, France, 2011.

19. Cardona, A.J.A.; Chica, C.A.P.; Barragán, D.H.O. Building-Integrated Photovoltaic Systems (BIPVS): Performance and Modeling Under Outdoor Conditions; Springer: Berlin, Germany, 2018.

20. Assoa, Y.B.; Mongibello, L.; Carr, A.; Kubicek, B.; Machado, M.; Merten, J.; Misara, S.; Roca, F.; Sprenger, W.; Wagner, M.; et al. Thermal analysis of a BIPV system by various modelling approaches. Sol. Energy 2017, 155, 1289-1299. [CrossRef]

21. Shukla, A.K.; Sudhakar, K.; Baredar, P.; Mamat, R. Solar PV and BIPV system: Barrier, challenges and policy recommendation in India. Renew. Sustain. Energy Rev. 2017, 82, 3314-3322. [CrossRef]

22. Heinstein, P.; Ballif, C.; Perret-Aebi, L. Building integrated photovoltaics (BIPV): Review, potentials, barriers and myths. Green 2013, 3, 125-156. [CrossRef]

23. Dehra, H. An investigation on energy performance assessment of a photovoltaic solar wall under buoyancy-induced and fan-assisted ventilation system. Appl. Energy 2017, 191, 55-74. [CrossRef]

24. Luo, Y.; Zhang, L.; Liu, Z.; Wu, J.; Zhang, Y.; Wu, Z.; He, X. Performance analysis of a self-adaptive building integrated photovoltaic thermoelectric wall system in hot summer and cold winter zone of China. Energy 2017, 140, 584-600. [CrossRef]

25. Martin, J., II. BIPV: Building-Integrated Photovoltaics, the Future of PV. 2011. Available online: http:/ / www.solarchoice.net.au/blog/bipv-building-integrated-photovoltaics-the-future-of-pv/ (accessed on 12 October 2016).

26. Hagemann, I. Shading systems with PV A new market for prefabricated building elements? In Environmentally Friendly Cities: Proceedings of Plea 1998, Passive and Low Energy Architecture, 1998, Lisbon, Portugal, June 1998; James \& James (Science Publishers) Ltd: London, UK, 2014; Volume 373.

27. Tablada, A.; Kosorić, V.; Huang, H.; Chaplin, I.; Lau, S.; Yuan, C.; Lau, S. Design Optimization of Productive Façades: Integrating Photovoltaic and Farming Systems at the Tropical Technologies Laboratory. Sustainability 2018, 10, 3762. [CrossRef]

28. Kahoorzadeh, A. Improvement of Thermal Comfort in Residential Buildings by Passive Solar Strategies Using Direct Gain Techniques. Ph.D. Thesis, Eastern Mediterranean University (EMU)-Doğu Akdeniz Üniversitesi (DAÜ), Famagusta, Norther Cyprus, 2013.

29. Pester, S.; Crick, F. Performance of Photovoltaic Systems on Non-Domestic Buildings; IHS BRE Press: St Albans, UK, 2013.

30. Taveres-Cachat, E.; Bøe, K.; Lobaccaro, G.; Goia, F.; Grynning, S. Balancing competing parameters in search of optimal configurations for a fix louvre blade system with integrated PV. Energy Procedia 2017, 122, 607-612. [CrossRef]

31. Zhang, W.; Lu, L.; Peng, J. Evaluation of potential benefits of solar photovoltaic shadings in Hong Kong. Energy 2017, 137, 1152-1158. [CrossRef]

32. Yoo, S.-H.; Lee, E. Efficiency characteristic of building integrated photovoltaics as a shading device. Build. Environ. 2002, 37, 615-623. [CrossRef]

33. Bahr, W. A comprehensive assessment methodology of the building integrated photovoltaic blind system. Energy Build. 2014, 82, 703-708. [CrossRef]

34. Nagy, Z.; Svetozarevic, B.; Jayathissa, P.; Begle, M.; Hofer, J.; Lydon, G.; Willmann, A.; Schlueter, A. The adaptive solar facade: From concept to prototypes. Front. Archit. Res. 2016, 5, 143-156. [CrossRef]

35. Pérez-Alonso, J.; Pérez-García, M.; Pasamontes-Romera, M.; Callejón-Ferre, A.J. Performance analysis and neural modelling of a greenhouse integrated photovoltaic system. Renew. Sustain. Energy Rev. 2012, 16, 4675-4685. [CrossRef]

36. Aksugur, E. Potential of passive cooling strategies in Cyprus. In Housing Research Conference, European Network in Housing Research; ENHR: Helsingor, Denmark, 1996; Volume 174.

37. Oktay, D. Design with the climate in housing environments: An analysis in Northern Cyprus. Build. Environ. 2002, 37, 1003-1012. [CrossRef]

38. iSHAN JAIN (2017) How to Design A Shading Device? Available online: http://talkarchitecture.in/how-todesign-a-shading-device/ (accessed on 7 August 2018). 
39. Kuhn, T.E.; Bühler, C.; Platzer, W.J. Evaluation of overheating protection with sun-shading systems. Sol. Energy 2001, 69, 59-74. [CrossRef]

40. Valladares-Rendón, L.G.; Schmid, G.; Lo, S. Review on energy savings by solar control techniques and optimal building orientation for the strategic placement of façade shading systems. Energy Build. 2017, 140, 458-479. [CrossRef]

41. Kirimtat, A.; Koyunbaba, B.K.; Chatzikonstantinou, I.; Sariyildiz, S. Review of simulation modeling for shading devices in buildings. Renew. Sustain. Energy Rev. 2016, 53, 23-49. [CrossRef]

42. Zhang, X.; Lau, S.; Lau, S.S.Y.; Zhao, Y. Photovoltaic integrated shading devices (PVSDs): A review. Sol. Energy 2018, 170, 947-968. [CrossRef]

43. James, T.; Goodrich, A.; Woodhouse, M.; Margolis, R.; Ong, S. Building-Integrated Photovoltaics (BIPV) in the residential sector: An analysis of installed rooftop system prices. Contract 2011, 303, 275-3000.

44. Weller, B. Detail Practice: Photovoltaics; Birkhäuser: Basel, Switzerland, 2010.

45. Leskovar, V.Ž.; Premrov, M. An approach in architectural design of energy-efficient timber buildings with a focus on the optimal glazing size in the south-oriented façade. Energy Build. 2011, 43, 3410-3418. [CrossRef]

46. Boxwell, M. The Solar Electricity Handbook-2017 Edition: A Simple, Practical Guide to Solar Energy-Designing and Installing Solar Photovoltaic Systems; Greenstream Publishing: Coventry, UK, 2017.

47. Ozay, N. A comparative study of climatically responsive house design at various periods of Northern Cyprus architecture. Build. Environ. 2005, 40, 841-852. [CrossRef]

48. TRNC (2006) TRNC General Population and Housing Unit Census. Available online: http://nufussayimi. devplan.org/Census\%202006.pdf (accessed on 5 December 2018).

49. Özdeniz, M.B.; Hançer, P. Suitable roof constructions for warm climates-Gazimağusa case. Energy Build. 2005, 37, 643-649. [CrossRef]

50. Hancer, P. Thermal Insulations of Roofs for Warm Climates. Ph.D. Thesis, Eastern Mediterranean University, Famagusta, Northern Cyprus, 2005.

51. ontheworldmap.com. Available online: http://ontheworldmap.com/cyprus/city/famagusta/famagustalocation-on-the-cyprus-map.jpg (accessed on 15 January 2019).

52. Lapithis, P.A. Passive solar architecture in Cyprus; Lapithis Architectural Firm: Lefkosa, Cyprus, 2005.

53. Climatemps.com. Available online: http://www.famagusta.climatemps.com/ (accessed on 14 August 2018).

54. Pourvahidi, P. Bioclimatic Analysis of Vernacular Iranian Architecture. Ph.D. Thesis, Eastern Mediterranean University (EMU), Famagusta, Northern Cyprus, 2010.

55. Atalar, E. Evaluation of Solar Insolation in Northern Cyprus. Ph.D. Thesis, Eastern Mediterranean University, Famagusta, Northern Cyprus, 2001.

56. Theodoros, Z.; Hadjikyriakou, C. State of the Art of Power Generation in Cyprus. In Social Costs and Benefits of Renewable Electricity Generation in Cyprus; Springer: Cham, Switzerland, 2016; pp. 7-16.

57. Solar resource map (c) 2018 Solargi. Available online: https:/ / solargis.com/maps-and-gis-data/download/ cyprus (accessed on 21 January 2019).

58. Energyplus (2018), EnergyPlus. Available online: https:/ / energyplus.net/ (accessed on 4 December 2018).

59. Reta, T. Leveraging a Building Information Model to Carry Out Building Energy Performance Analysis. Bachelor's Thesis, Helsinki Metropolia University of Applied Sciences, Helsinki, Finland, 2017.

60. Murray, M.; Liggett, R.; Benson, A.; Bhattacharya, Y. Climate Consultant 4.0 develops design guidelines for each unique climate. In American Solar Energy Society Meeting; ASES: Boulder, CO, USA, 2009.

61. Mesda, Y. Heat Transfer Coefficient Analysis of the Chamber of Cyprus Turkish Architects Office Building on the Zahra Street in the Walled City of Nicosia in Cyprus. Archit. Res. 2012, 2, 47-54. [CrossRef]

62. Optimum Tilt of Solar Panels. Available online: https://www.solarpaneltilt.com/ (accessed on 28 December 2018).

(C) 2019 by the authors. Licensee MDPI, Basel, Switzerland. This article is an open access article distributed under the terms and conditions of the Creative Commons Attribution (CC BY) license (http://creativecommons.org/licenses/by/4.0/). 